\title{
EFEKTIFITAS ALIH TEKNOLOGI TEPAT GUNA DALAM MANAJEMEN PRODUKSI VIRGIN COCONUT OIL (VCO) DI MASA PANDEMIK COVID-19
}

\author{
Agung Nusantoro'), Sugeng E.P.W. ${ }^{1)}$, Zulfanita ${ }^{1)}$, Agus Budi S. ${ }^{1)}$, Budi Setiawan'1) \\ 1)Universitas Muhammadiyah Purworejo, Purworejo, Jawa Tengah, Indonesia \\ Corresponden Author: Zulfanita \\ E-mail: zulfanita@umpwr.ac.id
}

Diterima 25 November 2021, Disetujui 01 Desember 2021

\begin{abstract}
ABSTRAK
Makalah ini akan memberikan paparan akan proses penumbuhan pengetahuan dan ketrampilan kepada Kelompok Usaha Bersama pada pembuatan Virgin coconut oil (VCO) di masa Pandemik Covid19. Kegiatan ini secara keseluruhan berlangsung selama 8 (delapan) bulan. Rangkaian kegiatan yang dilakukan terdiri dari (1) orientasi lokasi, (2) persiapan dan perencanaan pelatihan dan pendampingan, (3) kegiatan pelatihan, (4) pengamatan hasil pelatihan, dan (5) evaluasi terhadap pelatihan dan pendampingan. Pengumpulan data dari kajian ini dilakukan dengan metode observasi dan wawancara mendalam terhadap 8 informan yang menjadi peserta kegiatan. Berdasarkan pada hasil evaluasi dan pembahasan, maka dapat disimpulkan bahwa ibu-ibu dan remaja putri di Desa Bener, Kecamatan Bener, Purworejo sudah mulai menyadari dan mengerti pentingnya peranan pengembangan agroindustri khususnya minyak VCO sebagai sarana penunjang kesehatan dan menambah pendapatan keluarga. Salah satu bagian penting dari kegiatan ini adalah peserta mengetahui peluang dan tantangan agroindustri VCO dengan benar dalam upaya meningkatkan ketrampilan dan pendapatan dari bidang pertanian. Di sisi lain mereka juga bertambah pengetahuannya tentang teknologi pembuatan VCO pada skala rumah tangga secara optimal, dan mampu meningkatkan pendapatan di masa pandemic Covid19.
\end{abstract}

Kata kunci : virgin coconut oil (VCO); kelompok usaha bersama, pandemic; covid-19.

\begin{abstract}
This paper will explain the process of growing knowledge and skills to the Joint Business Group on the manufacture of virgin coconut oil (VCO) during the Covid-19 Pandemic. Overall this activity lasted for 8 (eight) months. The series of activities carried out consisted of (1) location orientation, (2) preparation and planning of training and mentoring, (3) training activities, (4) observation of training results, and (5) evaluation of training and mentoring. Data collection from this study was carried out using observation and in-depth interviews with eight informants who were participants in the activity. Based on the results of the evaluation and discussion, it can be concluded that women and young women in Bener Village, Bener District, Purworejo have begun to realize and understand the importance of the role of agroindustry development, especially VCO oil, as a means of supporting health and increasing family income. A critical part of this activity is that participants know the opportunities and challenges of the VCO agro-industry properly to improve skills and income from the agricultural sector. On the other hand, they have also increased their knowledge of optimal VCO manufacturing technology at a household scale and can increase revenue during the Covid-19 pandemic.
\end{abstract}

Keywords: virgin coconut oil (VCO); joint venture group, pandemic; covid-19

\section{PENDAHULUAN}

Angkatan kerja nasional yang diserap oleh kegiatan agribisnis nasional saat ini diperkirakan mencapai $70 \%$ dan melibatkan \pm $90 \%$ usaha kecil, menengah, dan koperasi. Bidang ini juga mampu menghidupi $\pm 80 \%$ penduduk Indonesia yang terdiri atas petani dan buruh tani, nelayan, peternak, pedagang sarana produksi pertanian, pedagang hasil pertanian dan produk olahan, serta orang-orang yang berkaitan dengan dengan bidang ini, baik secara langsung maupun tidak langsung (Retno L., 2011). Melihat kondisi tersebut, bagi masyarakat umum, peluang pengembangan kegiatan agribisnis sangat terbuka lebar. Pengembangan kegiatan agrobisnis tidak hanya bermanfaat bagi pertumbuhan ekonomi nasional namun juga upaya pengembangan ekonomi rakyat dapat lebih dijangkau. Salah satu komoditas yang dalam pengembangannya memerlukan dukungan dan kerjasama dengan berbagai subsistem adalah kelapa. Agribisnis 
kelapa sangat potensial dikembangkan di Indonesia, mengingat kelapa merupakan komoditas nasional yang dikonsumsi oleh hampir seluruh penduduk Indonesia, di samping juga dibudidayakan dan menjadi sandaran hidup jutaan petani. Kelapa mempunyai arti sosial ekonomi yang penting bagi Indonesia (Allolerun, Abner, 1998). Seluruh bagian dari pohon kelapa dapat dimanfaatkan, karena itu kelapa sering disebut dengan pohon kehidupan (tree of life) dan pohon surga (heavenly tree). Komoditas kelapa selama ini dan sebagian besar dimanfaatkan untuk kelapa sayur dan minyak makan dj beberapa tempat telah dikembangkan berbagai produk olahan dari kelapa dan pemanfaatkan hasil sampingannya, seperti dessicated coconut, nata de coco, serat serabut, dan arang aktif. Dibidang kesehatan, sampai sekarang khasiat kelapa uhtuk mendukung dan menjaga kesehatan telah semakin diakui. Meskipun demikian kelapa masih sering dipandang sebagai tanaman senja (sunset crop) yang tidak mampu bersaing dipasar ekspor (Ditjenbun, 1996).

Produk kelapa yang umumnya dijual oleh masyarakat masih terbatas pada kopra, minyak goreng, gula merah atau kelapa butiran. Sementara ini, baru industri besar yang telah mengolah seluruh komponen buah kelapa menjadi berbagai produk dengan nilai ekonomi tinggi. Pemanfaatan bagian buah kelapa menjadi produk olahan yang berfungsi sebagai obat dan bahan kosmetik seperti minyak kelapa murni (Virgin Coconut Oil) belum banyak dilakukan oleh petani maupun masyarakat umum. Salah satu penyebabnya adalah terbatasnya informasi pengolahan yang sampai kepada masyarakat dan petani (Masyhuri, 2000).VCO merupakan salah satu produk diversifikasi agroindustri berbahan baku kelapa. Produk ini diproses langsung dari daging buah kelapa segar atau santan segar tanpa pemurnian, pemutihan atau penghilangan bau. Berbagai manfaat dari produk VCO ini telah diungkap oleh banyak peneliti. Minyak kelapa murni sangat bermanfaat bagi kesehatan tubuh manusia. Manfaat VCO diantaranya adalah mengurangi resiko kanker, membantu mencegah infeksi virus, mendukung sistem kekebalan tubuh, mencegah osteoporosis, membantu mengontrol diabetes, memulihkan kembali kehilangan berat badan, menyediakan sumber energi dengan cepat, menyediakan nutrisi, membantu kulit tetap lembut dan halus, tidak menaikkan kolesterol darah, dan tidak menyebabkan kegemukan (Juli, 2014).
Oleh karena itu, teknologi pengolahan santan kelapa menjadi minyak kelapa murni dan bekal kemampuan berbisnis/wirausaha penting untuk disebarluaskan agar masyarakat dapat menerapkan teknologi tersebut di lingkungan mereka, khususnya dalam usaha skala kecil (home industry). Bila upaya pengembangan pengolahan minyak kelapa murni berhasil, berarti satu nilai tambah lagi dari buah kelapa dapat dirasakan manfaatnya oleh masyarakat. Terjalinnya interaksi antara sumber daya manusia (SDM) dengan sumber daya alam (SDA) di daerah juga dapat tetap terjaga, yang secara tidak langsung berarti upaya pengelolaan lingkungan juga dapat berjalan dengan baik (Listyati, Sudjarmoko, 1998). Pada umumnya masyarakat pedesaan khususnya ibu rumah tangga dan remaja putri menyukai teknologi baru yang berkaitan dengan usaha industri rumah tangga (Purwadi, Musita, 1998). Mereka tergerak untuk mempelajari ketrampilan baru dan mencobanya sebagai pengisi waktu luang bahkan ada beberapa yang menekuninya secara serius dan mengembangkannya menjadi industry rumah tangga yang memberikan keuntungan dan menambah pendapatan rumah tangga.

Masyarakat Desa Bener, Kecamatan Bener Kabupaten Purworejo pada umumnya menanam tanaman kelapa di ladang dan pekarangan rumahnya. Selama ini buah kelapa yang dihasilkan dari pekarangan mereka langsung dijual pada tengkulak atau pedagang keliling dengan harga yang sangat murah yaitu sekitar Rp.300-Rp.400/butir kelapa, padahal kalau buah kelapa tersebut terlebih dahulu melalui proses pengolahan maka produk olahan yang dihasilkan memiliki nilai jual berlipat ganda dibandingkan apabila dijual dalam bentuk butiran kelapa. Namun kendala yang dihadapi pada umumnya adalah minimnya ketrampilan dan pengetahuan ibu-ibu dan remaja putri di Desa Bener dalam pengolahan kelapa menjadi produk olahan yang memiliki nilai jual lebih tinggi. Melihat kenyataan tersebut membuka peluang bagi kita untuk lebih meningkatkan nilai jual buah kelapa yang ada dengan terlebih dahulu memproses buah kelapa tersebut menjadi produk olahan yang memiliki nilai ekonomis lebih tinggi. Salah satu upaya yang dapat dilakukan yaitu dengan memberikan pelatihan cara memproses buah kelapa menjadi produk olahan minyak kelapa murni (Virgin Cocconut Oil) yang banyak diminati oleh masyarakat sebagai bahan baku obat dan kosmetika yang memiliki nilai jual cukup tinggi (Listyati, Sudjarmoko, 1998). 


\section{METODE}

Pada tahap awal, dilakukan stimulus berupa kegiatan dengan menggunakan metode pendidikan dan latihan. Pendidikan dilakukan dengan cara memberi penyuluhan kepada khalayak yang menjadi sasaran kegiatan, yaitu ibu rumah tangga dan remaja putri. Dipilihnya ibu rumah tangga dan remaja putri sebagai khalayak sasaran karena dianggap mampu dan mau untuk dilibatkan dalam kegiatan ini. Penyuluhan diberikan dengan tujuan untuk memberi pengetahuan dan wawasan bagi khalayak sasaran mengenai VCO, baik itu mengenai manfaat maupun cara pembuatannya.

Kegiatan pelatihan pembuatan VCO dilakukan dalam upaya memberikan pemahaman tentang cara pembuatan VCODalam pelatihan diperkenalkan dua cara pembuatan VCO, yaitu cara fermentasi dan cara sentrifuge. Untuk mengetahui keberhasilan kegiatan, evaluasi dilaksanakan dengan cara menggunakan pre test dan post test, serta pengamatan terhadap hasil pelatihan. Disamping itu, metode pengumpulan data terkait hasil dari stimulus yang dilakukan dalam kegiatan ini adalah menggunakan metode wawancara mendalam kepada 8 informan peserta kegiatan.

\section{HASIL DAN PEMBAHASAN}

Berdasarkan hasil orientasi dan observasi awal diketahui bahwa permasalahan yang paling mendesak untuk dipecahkan pada umumnya adalah mengenai kondisi dan situasi masyarakat yang belum mengetahui manfaat pengolahan produk kelapa berupa Virgin coconut oil (VCO), penggunaan teknik teknologi tepat guna dalam pengolahan VCO bagi peningkatan pendapatan keluarga maupun untuk kesehatan. Pernyataan ini sesuai dengan fakta yang menunjukkan para peserta umumnya belum sepenuhnya menekuni pembuatan VCO, padahal kegiatan ini memberikan manfaat yang cukup besar bagi kesehatan keluarga dan dapat memberikan pemasukan keluarga yang menekuni agroindustri kelapa ini.

Begitu juga tentang informasi konsep pengolahan produk kelapa berupa pembuatan VCO pada skala rumah tangga belum banyak yang menekuninya. Kenyataan ini seiring dengan keadaan dimana peserta masih beranggapan bahwa VCO masih berupa komoditas sampingan saja dan belum intensif dikelola oleh masyarakat, padahal VCO banyak memberikan manfaat sebagai sumber pendapatan keluarga.

Selama ini masyarakat Desa Bener belum begitu serius menekuni bidang
Agroindustri khususnya pengolahan produk kelapa berupa VCO dan agribisnisnya. Sebagai konsekuensinya, VCO yang menjanjikan peluang pasar dan pendapatan keuntungan yang besar belum dapat digali dan dimanfaatkan sebagai sumber pendapatan keluarga.

Masyarakat di Desa Bener, Kecamatan Bener, Kabupaten Bener ternyata belum memperhatikan aspek pengembangan usaha agroindustri VCO khususnya tentang peluang dan tantangan yang dihadapi. Hasil observasi awal juga menunjukkan bahwa peserta kurang mengetahui faktor-faktor yang mempengaruhi agar produk olahan kelapa berupa VCO memiliki kualitas dan mutu yang baik sehingga memiliki nilai jual yang tinggi. Hal ini terbukti dari cara pengolahan yang dilakukan kurang memperhatikan aspek kualitas dimana pada umumnya peserta belum memperhatikan aspek kebersihan pada saat proses pembuatan VCO khususnya pada saat penyaringan minyak, sehingga masih banyaknya blendo yang terbawa dan ternyata berpengaruh pada kejernihan minyak yang dihasilkan.

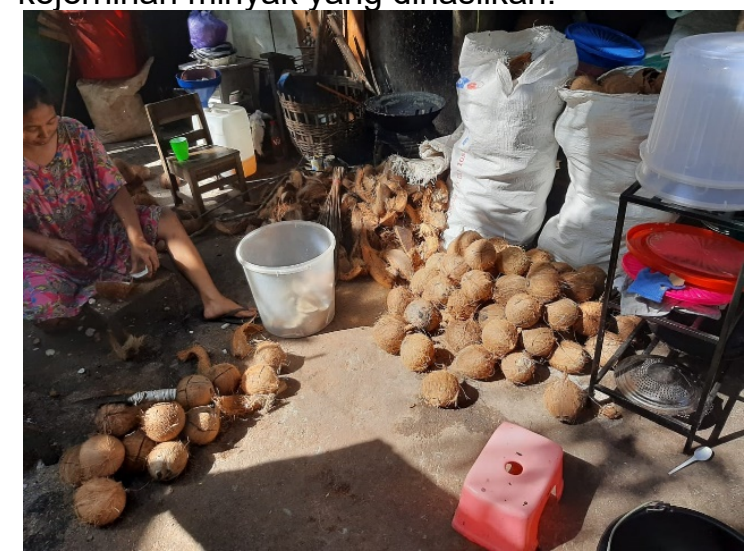

Gambar 1. Pengolahan Buah Kelapa dan Potensi Bahan Baku VCO di Desa Bener

Selain kejernihan minyak yang kurang baik, proses penyaringan yang kurang sempurna dapat menyebabkan daya simpan minyak menjadi lebih singkat (tidak awet), hal ini dapat terbukti hanya dalam kurun waktu 3 (tiga) bulan minyak menjadi tengik [4]. Untuk mengatasi permasalahan tersebut dilakukan upaya penyaringan ulang untuk minyak VCO yang sudah disimpan kurang lebih 1 (satu) minggu, dimana blendo yang terbawa pada saat proses penyaringan sudah mengalami pengendapan sehingga minyak VCO yang ada pada bagian atas sudah tidak mengandung blendo dapat diambil ulang dan ditempatkan pada botol-botol tertutup.

Berkaitan dengan upaya pemecahan serangkaian masalah pengembangan usaha agroindustri kelapa berupa pembuatan minyak VCO di kalangan ibu-ibu dan remaja putri di 
Desa Bener, maka telah diadakan serangkaian kegiatan yang menyadarkan akan pentingnya upaya tersebut terutama dalam rangka meningkatkan ketrampilan, yaitu berupa pelatihan.

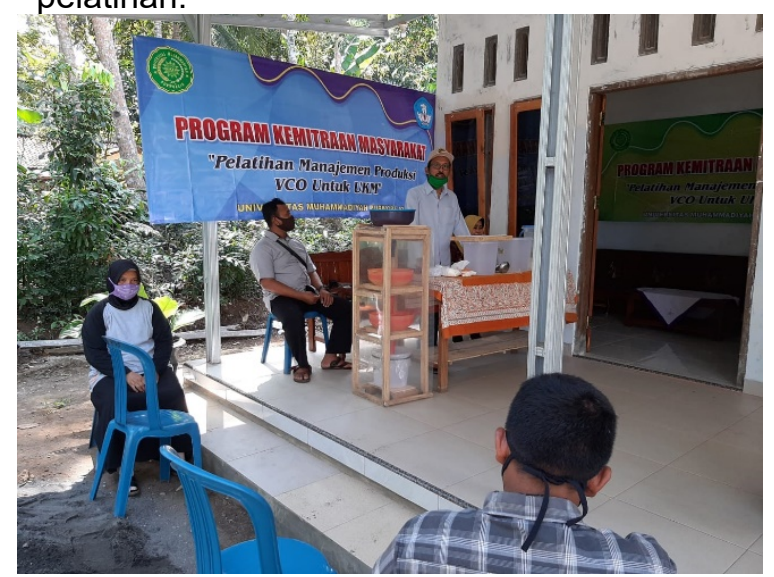

Gambar 2. Pelatihan Manajemen Produksi

Stimulus pada kegiatan ini adalah
berupa diselenggarakan dalam upaya menanamkan kesadaran, pengertian dan ketrampilan pengembangan agroindustri kelapa berupa minyak VCO yang dikelola pada skala rumah tangga di Desa Bener, Kecamatan Bener, mendapat respon yang cukup baik dari ibu-ibu PKK dan remaja putri. Hal ini terbukti dari jumlah peserta yang mengikuti pelatihan pada setiap kali diadakan kegiatan transfer teknologi tersebut baik pada saat pemberian materi maupun pada saat praktikum pembuatan VCO. Pertanyaan yang bervariasi dan keingintahuan peserta tentang upaya pengembangan usaha pembuatan VCO, dalam acara pemberian materi maupun praktek langsung menunjukkan bahwa sebenarnya mereka telah lama ingin memperoleh materi atau informasi yang berkaitan dengan teknologi tepat guna. Kenyataan ini menyiratkan bahwa meskipun selama ini transfer teknologi terutama teknologi pertanian sebagai kegiatan sambilan, namun ternyata dikalangan wanita terdapat minat dan motivasi yang cukup besar untuk mengadopsi upaya pengembangan agroindustri kelapa yang mana merupakan produk pertanian yang banyak terdapat di Desa Bener.

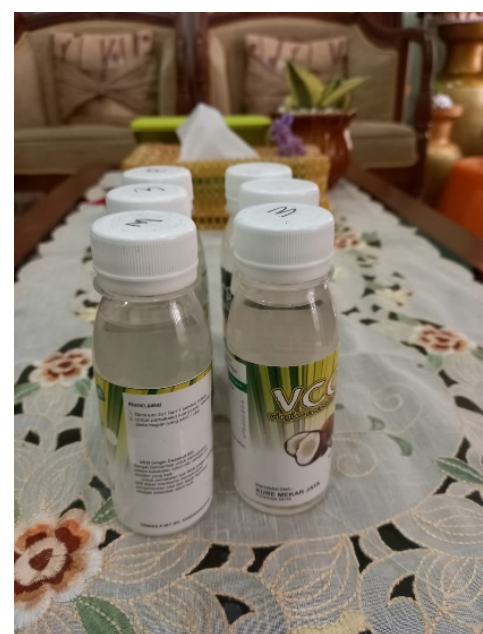

Gambar 3. Produk VCO KUB "Mekar Jaya"

Dari hasil evaluasi yang dilakukan setelah pelatihan maka dapat diamati bahwa pemahaman sekitar 90 persen peserta sampel terhadap materi dan praktek pembuatan VCO tergolong baik. Mereka sudah mulai mengetahui dan sebagian mempraktekkannya di rumah bahkan menularkan pengetahuan mereka kepada ibu-ibu yang lain pada saat diselenggarakannya pertemuan PKK pada tingkat RW maupun RT di tempat tinggalnya masing-masing, hal ini dilakukan dalam rangka lebih meningkatkan ketrampilan yang telah mereka peroleh selama pelatihan.

Sebagai informasi bahwa jumlah ibuibu dan remaja putri yang mencoba mempraktekkan pembuatan VCO pada saat ini sudah bertambah jumlahnya. Hal ini menunjukkan bahwa pelatihan yang diberikan berhasil dalam menanamkan kesadaran bagi para ibuibu dan remaja putri akan hal-hal yang inovatif dan berguna.

Disamping adanya beberapa faktor pendorong, maka kegiatan pengabdian ini juga dipengaruhi oleh adanya beberapa faktor penghambat. Faktor yang perlu segera diantisipasi adalah masih belum memasyarakatnya manfaat dan kegunaan VCO bagi kesehatan, sehingga masyarakat masih belum berminat mengkonsumsi produk olahan kelapa ini sebagai bahan alternatif yang dapat meningkatkan dan menjaga kesehatan, sehingga adanya hambatan dalam hal pemasaran VCO dikalangan masyarakat desa. Hal ini disebabkan kurangnya sosialisasi di tingkat pedesaan akan manfaat produk olahan VCO ini bagi kesehatan.

Untuk menumbuhkan agroindustri sangat dibutuh sumber daya manusia (SDM) yang memiliki motivasi yang tinggi untuk berusaha. Keuletan SDM akan mendorong pelaku usaha tanggap terhadap setiap peluang yang ada dan dengan tangguh mengatasi segala hambatan yang dihadapi. Faktor internal 
lain yang menjadi kekuatan dalam agroindustri VCO adalah tingkat ketrampilan SDM. Tenaga kerja yang terampil sangat diperlukan dalam agroindustri VCO. Pada umumnya ketrampilan tenaga kerja diperoleh melalui pelatihan yang diprakarsai oleh Pemerintah Daerah Purworejo. Tenaga kerja yang digunakan dalam agroindustri VCO di Kulon Progo berasal dari wilayah setempat. Pengusaha agroindustri VCO (dalam kategori industri kecil) di Kabupaten Kulon Progo selalu berupaya untuk meningkatkan standar kualitas produk yang diinginkan. Hal ini dilakukan untuk meningkatkan kualitas VCO yang dihasilkan, sehingga akan mendapat kepercayaan dari konsumen. Upaya yang dilakukan untuk menjaga kualitas VCO yang dihasilkan adalah dengan penggunaan bahan baku yang berkualitas maupun pengujian laboratorium.

\section{SIMPULAN DAN SARAN Simpulan}

Berdasarkan pada hasil evaluasi dan pembahasan seperti yang telah diuraikan maka dapat diambil kesimpulan sebagai berikut : 1). Kelompok mitra menyadari dan memahami pentingnya peranan pengembangan agroindustri khususnya minyak VCO sebagai sarana penunjang kesehatan dan menambah pendapatan keluarga, 2). Peluang dan tantangan agroindustri VCO dapat dipahami peserta dengan benar, sehingga ada upaya meningkatkan ketrampilan dan pendapatan dari bidang pertanian, 3). Peserta bertambah pengetahuannya tentang teknologi pembuatan VCO pada skala rumah tangga secara optimal, 4). Ketersediaan dan kontinyuitas ketersediaan dan kualitas bahan baku merupakan kekuatan dalam pengembangan agroindustri VCO disamping factor motivasi pelaku usaha ketrampilan SDM dan tingkat adopsi teknologi.

\section{Saran}

Sehingga dapat disarankan agar upaya pengembangan agroindustri kelapa khususnya VCO pada skala rumah tangga dapat berlangsung secara intensif dan berkelanjutan di kalangan generasi muda, maka perlu diadakan sosialisasi secara intensif mengenai usaha pembuatan minyak VCO disertai peningkatan peran instruktur yang tetap dibutuhkan untuk mendampingi para peserta dalam melakukan kegiatan ini.

\section{DAFTAR RUJUKAN}

Retno L., (2011). Strategi Pengembangan Agroindustri VCO di Kabupaten Kulonprogo, AGRISEF. 10.

Allolerung,D. dan Abner Lay. (1998). Kemungkinan Pengembangan
Pengolahan Buah Kelapa secara Terpadu Skala Pedesaan. Dalam : Prosiding Konferensi Nasional Kelapa IV. Bandar Lampung.

Ditjenbun, (1996). Statistika Perkebunan Indonesia. Direktorat Jendral Perkebunan, Jakarta.

Rindengan, B dan Novarianto, H (2004), Pembuatan dan Pemanfaatan Minyak Kelapa Murni. Swadaya, Jakarta.

Masyhuri, (2000). Pengembangan Agroindustri melalui Penelitian dan Pengembangan Produk yang Intensif dan Berkesinambungan. Agro Ekonomi. $7(1): 1-10$.

Juli Soemirat, (2014). Kesehatan Lingkungan, Yogyakarta: Gadjah Mada University Press.

Listyati, Dewi dan Beni Sudjarmoko, (1998). Keragaman Agribisnis kelapa di Indonesia. Dalam : Prosiding Konferensi Nasional Kelapa IV. Bandar Lampung.

Purwadi dan Nanti Musita, (1998). Teknologi Agroindustri kelapa yang Sesuai Untuk Pedesaan. Dalam : Prosiding Konferensi Nasional Kelapa IV. Bandar Lampung. 